\title{
THE LARVAL Fish FAUNA OF THE “CANAL DE SANTA CRUZ” ESTUARY IN NORTHEAST BRAZIL.
}

\author{
WERNER EKAU 1 \\ PETRA WESTHAUS-EKAU ${ }^{1}$ \\ SILVIO JOSÉ DE MACÊDO \\ CHRISTIAN VON DORRIEN ${ }^{1}$
}

1) Center for Tropical Marine Ecology, Bremen, Germany

2) Federal University of Pernambuco, Recife, Brazil

\begin{abstract}
The ichthyoplankton fauna of a mangrove estuary in Northeast Brazil, the "Canal de Santa Cruz" was investigated. The larval distribution in the channel was analysed based on 187 samples from 9 stations collected from November 1993 to May 1994. 50 of these samples were used to investigate the taxonomic composition. Larval densities varied between 0 and 376 ind. per $50 \mathrm{~m}^{3}$. Seasonal and geographical patterns were found. Both in dry and rainy season larval abundance was low at the inner channel. Except a few hauls, most samples did not exceed densities of 25 or 45 ind. $/ 50 \mathrm{~m}^{3}$, respectively. High concentrations beyond 100 ind. per $50 \mathrm{~m}^{3}$ were found at station 2,3 and once at station 8 in the northern part and at station 7 in the southern part of the channel. Engraulidae larvae and different types of Gobiidae were the dominant groups in the channel. These two families reached almost $76 \%$ of the whole ichthyoplankton in the catches. They are followed by Achiridae, Clupeidae, Terapontidae, Sciaenidae, Tetraodontoidei, Carangidae, Syngnathidae, Cottidae (?) and Blennioidei (summing up to 95\% of the caught fish larvae in the channel). Nearly all groups are found as adults in the channel. Only five families are represented exclusively by larvae: Achiriidae, Cottidae, Terapontidae, Exocoetidae and Ephippidae. From the latter, only Exocoetidae form an oceanic group. Based on the taxa composition, it is assumed, that the importance of the estuary as nursery ground for shelf and oceanic fish is low.
\end{abstract}

Key words: Ichthyoplankton; estuary; larval distribution;

\section{INTRODUCTION}

Mangrove forests are a typical coastal biotope of the tropics. Situated between the land and the sea, this amphibious ecosystem is confronted with human impacts from various sides: atmospheric pollution, riverine and terrestrial influx as well as coastal developments, and marine pollution and over-fishing. The decline of mangrove forests would entail a loss of this important and unique ecosystem with its irretrievable wealth of biodiversity.

Mangrove forests are frequented by a diverse variety of animal taxa for their maturation. Larval and juvenile fishes and prawns encounter a rich diet on the roots and in the sediment. Many fish species from shelf seas use mangrove forests as nurseries where they spend at least their juvenile stages (Blaber et al. 1985; Robertson and Duke, 1987; Blaber et al. 1989; Louis et al. 1992; Thollot, 1992; Blaber et al. 1995).

Tropical Oceanography, Recife: v. 29, n. 2, p. 117-128, 2001. 


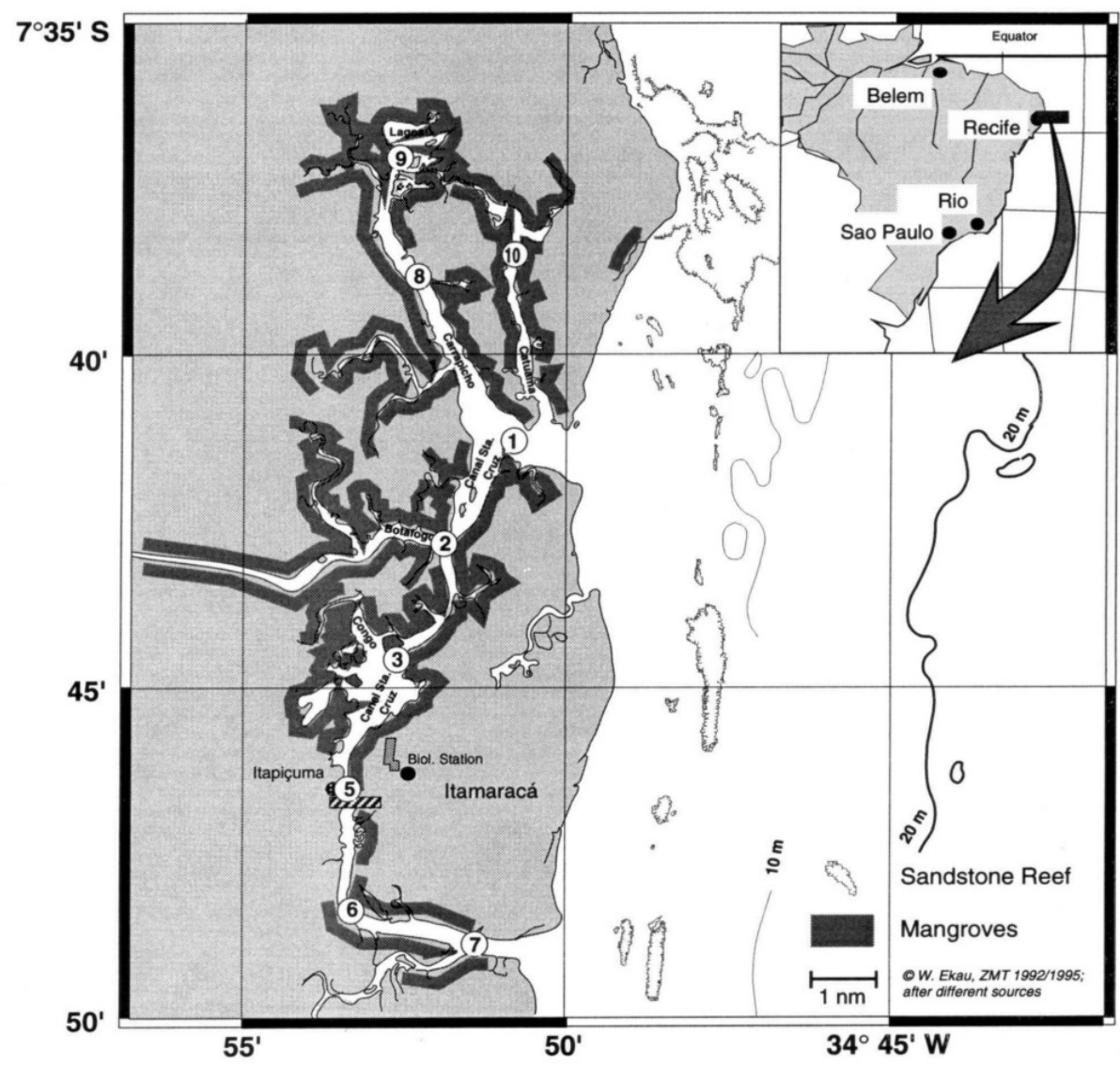

Figure 1 - Map of the investigation area and the sampling sites. The estuary is a u-shaped channel with two exits to the Atlantic Ocean, and a loop of two small rivers in the north. The channel has a length of about $20 \mathrm{~km}$ and an area of $22 \mathrm{~km}^{2}$. Mean depth is $8 \mathrm{~m}$ in the North and $4 \mathrm{~m}$ in the South. Stations 1 to 7 were adopted from former works of the Oceanographic Department of UFPE, of which station 4 was dropped because of the close neighbourhood to station 3.

On the other hand, estuarine species spawn within the mangrove areas or rivers and their brood is spoiled out into the adjacent marine habitats to pass over a certain developmental period. This export of young stages enriches the coastal waters and increases its diversity.

The artisanal fishery depends strongly on the estuarine species. Chong (1987) has found a strong geographical relationship between fishing grounds and distribution of coastal mangroves. The long-term loss for the fishery following the destruction of nursery areas for fishes and prawns exceeds short-termed profits from logging or other commercial exploitation of mangroves (Whitten et al., 1984).

Information on the larval fish fauna in the brackish waters of Northeast Brazil is not available. A list of adult species in the estuaries of Pernambuco is given by different authors (Eskinazi 1972; review by Macedo and Koening, 1987).

The aim of this study was to investigate the ichthyoplankton fauna in order to estimate the importance of the estuary as nursery area for commercially exploited fish species in an estuary in 
NE-Brazil and in the adjacent coastal waters. This study was part of a cooperational project on the "Ecology of the Canal de Santa Cruz" between the Department of Oceanography of the Federal University of Pernambuco and the Center for Tropical Marine Ecology.

\section{MATERIAL AND Methods}

\section{Investigation Area}

The investigation area is the "Santa Cruz Channel" (CSC), a tropical mangrove estuary in the Brazilian state of Pernambuco (fig. 1).

The estuary is a u-shaped channel with two exits to the Atlantic Ocean. The channel has a length of about $20 \mathrm{~km}$ and an area of $22 \mathrm{~km}^{2}$. Mean depth is $8 \mathrm{~m}$ in the North and $4 \mathrm{~m}$ in the South. Water temperature varied during sampling period between 25 (Rainy Season) and $30{ }^{\circ} \mathrm{C}$ (Dry Season), salinity between 14 and $38 \times 10^{-3}$, respectively. The general hydrographic situation in the investigation area and the position of the stations is described in detail by Medeiros \& Macedo (this volume).

\section{Material}

Distribution in the channel was analysed based on 187 hauls at 9 stations in the estuary (1 to 3, 5 to 10; circles in the map) for a period of November 1993 to May 1994. 50 of these samples were used to investigate the taxonomic composition. Stages of larval development were classified after Russell (1976). Larvae were identified after several authors: Fahay (1983), Boltovskoy (1981), Ahlstrom and Moser (1984), Leis and Trnski (1989), Anonymous (1978), Leis and Rennis (1983) and W. Richards (pers. comm) for general classification. For Gobiidae and Sciaenidae special publications were used:

Gobiidae were identified specially after: Ahlstrom and Moser, 1984; Wyanski and Targett, 1985; Peters, 1983; Pezold and Gilbert, 1987; W. Richards, pers. comm.; Foster and Fuiman, 1987; Okiyama, 1988; Anon, 1978 vol. V. Pigment pattern and development of ventral fins in relation to body length were not totally corresponding to descriptions from literature. Therefore the larvae were grouped only into different form types and unidentifiable yolk sac larvae after Foster and Fuiman (1987), Okiyama (1988) and Anonymous (1978 vol. V). Names of genera and species given in brackets show the nearest conformity with these taxa.

Sciaenidae were identified after: Sinque, 1980; Powles and Stender, 1978; Ditty and Shaw, 1994; Ditty, 1989. Four species are described by Macedo and Koening (1987) to represent the family in the adult fish community in the channel: Bairdiella ronchus, Cynoscion leiarchus, Menticirrhus americanus and Micropogonias furnieri. Based on pigment pattern and body shape, the sciaenid larvae could not be defined to belong to these species. They were grouped into 4 types. Larvae from type II show a large conformity to the genus Bairdiella, larval descriptions of $B$. ronchus, however, do not exist.

For the species of Engraulidae occurring in the channel as adults, no larval descriptions exist except for the genus Cetengraulis. The specimens identified as Anchoa sp. were already juvenile.

The results of total abundance and taxonomic composition were analysed on a monthly and a seasonal base. Dry Season was represented by samples from September to January, Rainy Season by samples from February to August (after Medeiros and Kjerfre, 1993).

Catches from August 1993 to April 1994 were done during day with a Bongo net $(\varnothing 60 \mathrm{~cm}$, mesh size $500 \mu \mathrm{m}$ ). In May 1994, day and night catches were performed. These samples were used for a day/night comparison of abundance and species composition. Hauls were conducted

Tropical Oceanography, Recife: v. 29, n. 2, p. 117-128, 2001. 
horizontally in the nearsurface layer $(<1 \mathrm{~m})$. Sampling at all 9 stations was conducted during a time window of 4 hours around high tide or low tide, respectively. A regrouping of the samples for the analysis of the data, however, had to be done afterwards into high-, ebb-, low- and flood- tide. High and low tide were restricted to the time span of 1 hour before and after nominal tides for the port of Recife.

Samples were preserved immediately after the catch in $4 \%$ formalin, and transferred into preservation fluid (Steedman, 1976) before sorting.

\section{RESULTS}

\section{Total abundance}

The variability in the total larval abundance was very high. Densities varied between 0 and 376 ind. per $50 \mathrm{~m}^{3}$ (fig. 2). Seasonal and geographical patterns were found in the distribution. Both in dry and rainy season larval abundance was low at the inner channel stations 5 and 6 and in the northern "loop", a subsystem formed by the rivers "Catuama" and "Carapicho" (stations 8, 9, 10). Except a few hauls, most samples did not exceed densities of 25 or 45 ind./50 m³ , respectively. High concentrations beyond 100 ind. per $50 \mathrm{~m} 3$ were found at station 2, 3 and once at station 8 in the northern part and at station 7 in the southern part of the channel. Comparing the mouth stations 1 and 7 , only the southern one showed high values up to 240 ind./50 $\mathrm{m}^{3}$. In the north high concentrations of up to 380 ind./50 $\mathrm{m}^{3}$ were found only at the more interior station 2 .

On an average, fish larvae show similar abundance in North and South stations (fig. 3). No clear difference is seen between the hydrologically different parts of the channel. The "loop" samples showed less larval densities in both seasons, indicating separate system conditions than the other channel parts. Seasonal differences are not strongly pronounced, too.

Samples from May 1994 were not included in the rainy season groups, because all values found were unexpectedly low. They served, however, for a comparison of day and night catches. Day catches were found to have much lower values than night catches, representing an average of 5.2 or 10.2 , a median of 3.1 or 5.7 , and a maximum of 17.1 or 63.8 larvae per $50 \mathrm{~m}^{3}$, respectively (fig. 3). 


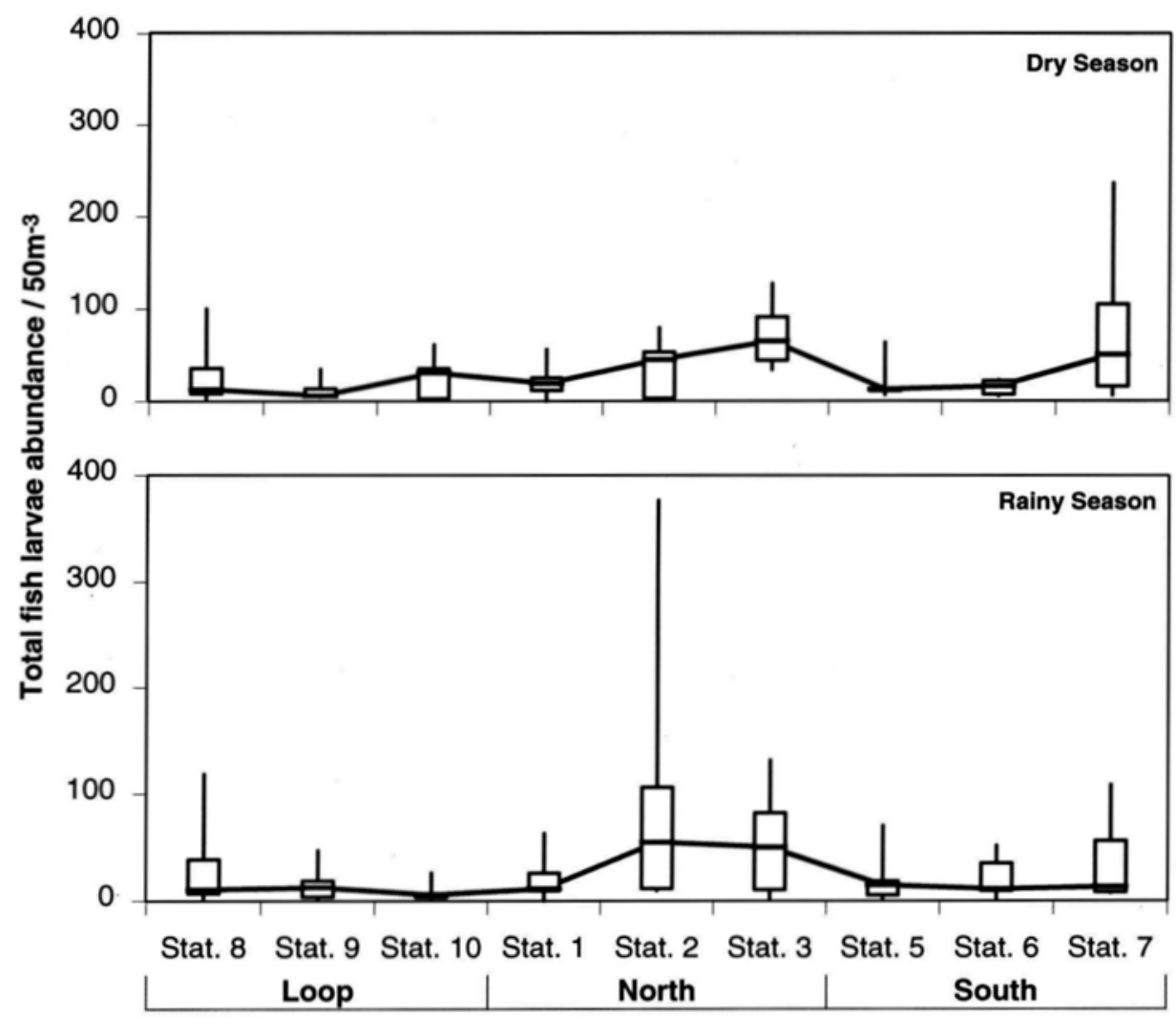

Figure 2 - Total fish larvae abundance, given in individuals per $50 \mathrm{~m}^{3}$, at the different stations. Samples are clumped for Dry (September to January) and Rainy Season (February to August). Given are the minimum, 25\% quartile, median, $75 \%$ quartile and maximum value per station in each season.

\section{Species composition}

From a total of 2711 fish larvae a number of 2221 could be identified to family, genus or even species level (tab. 1), 60 specimens were grouped into orders and 38 could not be identified at all. 392 specimens were found to be unidentifiable yolk sac larvae. A total of 9294 fish eggs were found in the samples, from which 2091 were identified as engraulid eggs.

Engraulid larvae (indet. and Anchoa sp.) and different types of Gobiidae were the dominant groups in the channel (tab. 1) with 1046 and 680 specimens, respectively. These two families contributed almost $76 \%$ of the whole ichthyoplankton in the catches. They were followed by Achiridae (Achirus spp.; 114 ind. / 5,0\%) and Clupeidae (87 ind. / 3,8 \%). Adding Terapontidae, other Sciaenidae, Tetraodontoidei, three Carangidae, Syngnathidae, Cottidae (?) and Blennioidei, these groups sum up to 95\% of the caught fish larvae in the channel. The catches from May 1994 showed, that most of the taxa were more abundant during night. Some were present only at night like Syngnathus sp. or Anchoa sp.. Specially the gobiid larvae preferred the night time. 


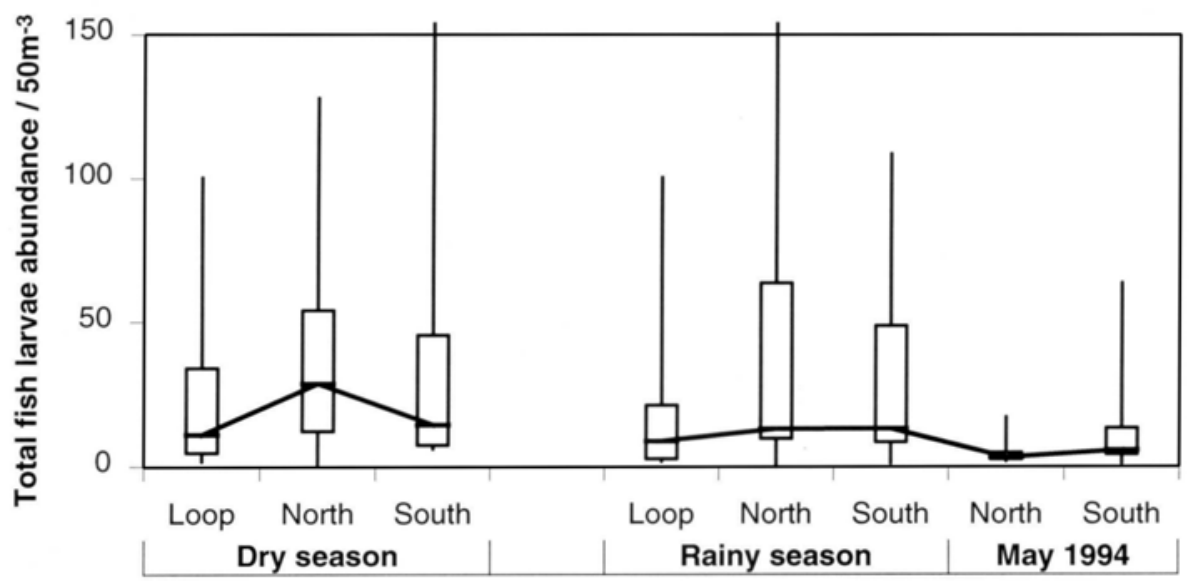

igure 3 - Total fish larvae abundance, given in individuals per $50 \mathrm{~m}^{3}$. Samples are clumped for areas and seasons: Dry (September to January) and Rainy Season (February to August), Loop (Stations 8,9 and 10), North (Stations 1, 2 and 3), South (Stations 5, 6 and 7). Given are the minimum, $25 \%$ quartile, median, $75 \%$ quartile and maximum value per station in each season.

Significant differences were also found in the seasonal and regional distribution of the taxa (fig. 4). Engraulidae were found in all parts of the channel with a relative abundance of 20 to $50 \%$. The Gobiidae seemed to prefer the southern area. Specially yolk sac larvae were found in higher concentrations indicating spawning activities in this part. A high abundance in November at station 7 was caused by a single peak of possibly gobiid yolk sac larvae dominating the sample.

Clupeiform larvae (possibly also Engraulidae) were abundant mainly during the dry season and in the north with a relative maximum in the "loop"-stations. They were mostly absent in the southern channel.

Achiridae with the dominating genus Achirus were found in the whole channel, showing a predominance in the "loop" and a slight decrease towards the southern channel parts.

Sciaenidae tended to increase concentrations in the dry season occurring mainly in the northern part. During the rainy season only few specimens were caught in the north.

Yolk sac larvae (Engraulidae, Gobiidae and Tetraodontoidei) were found mainly during the dry season in the south indicating spawning activity in this region and period. The grouping "others" includes a large part of unidentified yolk sac larvae, specially in the "Dry season south" category. 
Table 1 - Dominance of the different taxa, sorted by number of absolute counts in the samples. A comparison of day and night was only possible for catches in May 1994. "Presence" gives the number of samples where the taxa occurred. "Counts" gives the absolute number of larvae caught. Total number of samples analysed was 50, 30 of which were used for comparing day and night catches (15 each). Names of genera and species given in brackets show the nearest conformity with the form types. indet.: not identified.

\begin{tabular}{|c|c|c|c|c|c|c|}
\hline \multirow[t]{2}{*}{ Family } & \multirow[t]{2}{*}{ Species } & \multirow{2}{*}{$\begin{array}{l}\text { Total } \\
\text { Counts }\end{array}$} & \multicolumn{2}{|c|}{$\begin{array}{l}\text { Day catches } \\
\text { (only May '94) }\end{array}$} & \multicolumn{2}{|c|}{$\begin{array}{l}\text { Night catches } \\
\text { (only May '94) }\end{array}$} \\
\hline & & & Presence & Counts & Presence & Counts \\
\hline Engraulidae & indet. & 1036 & 13 & 136 & 13 & 294 \\
\hline Gobiidae (?) & Yolk sac larvae & 332 & 4 & 11 & 2 & 6 \\
\hline Gobiidae & type II (Microgobius thalassinus) & 270 & 3 & 5 & 11 & 118 \\
\hline Achiridae & Achirus spp. & 114 & 7 & 10 & 6 & 9 \\
\hline Clupeidae & & 87 & 3 & 3 & 5 & 81 \\
\hline Gobiidae & type I (Gobionellus sp.) & 67 & 0 & 0 & 9 & 34 \\
\hline Terapontidae & & 41 & 0 & 0 & 0 & 0 \\
\hline Sciaenidae & type II (Bairdiella sp.) & 38 & 0 & 0 & 0 & 0 \\
\hline Tetraodontoidei & Yolk sac larvae & 27 & 2 & 2 & 5 & 13 \\
\hline Carangidae & Seriola sp. & 23 & 6 & 7 & 2 & 2 \\
\hline Syngnathidae & Syngnathus sp. & 22 & 0 & 0 & 7 & 15 \\
\hline Cottidae? & & 21 & 1 & 5 & 1 & 1 \\
\hline Blennioidei & & 16 & 1 & 1 & 4 & 6 \\
\hline Sciaenidae & type III & 14 & 0 & 0 & 1 & 1 \\
\hline Carangidae & Oligoplites sp. & 13 & 0 & 0 & 0 & 0 \\
\hline Carangidae & Chloroscombrus chrysurus & 10 & 0 & 0 & 0 & 0 \\
\hline Sciaenidae & type IV & 10 & 1 & 1 & 0 & 0 \\
\hline Gobiidae & type IV (Bathygobius sp.) & 10 & 0 & 0 & 0 & 0 \\
\hline Engraulidae & Anchoa sp. & 10 & 0 & 0 & 4 & 10 \\
\hline Carangidae & indet. & 9 & 0 & 0 & 0 & 0 \\
\hline Tetraodontoidei & & 8 & 1 & 1 & 2 & 2 \\
\hline Sciaenidae & type I & 6 & 0 & 0 & 3 & 6 \\
\hline Blenniidae & & 5 & 0 & 0 & 0 & 0 \\
\hline Syngnathidae & Hippocampus sp. & 5 & 2 & 2 & 1 & 1 \\
\hline Gobiesocidae & & 5 & 0 & 0 & 1 & 1 \\
\hline Sciaenidae & Pogonias chromis & 3 & 0 & 0 & 0 & 0 \\
\hline Achiridae & indet. & 3 & 2 & 2 & 1 & 1 \\
\hline Exocoetidae & Hyporhamphus sp. & 2 & 0 & 0 & 0 & 0 \\
\hline Gerreidae & & 2 & 1 & 1 & 0 & 0 \\
\hline Tetraodontidae & Sphoeroides sp. & 2 & 0 & 0 & 0 & 0 \\
\hline Atherinidae & & 2 & 0 & 0 & 2 & 2 \\
\hline Engraulidae & Yolk sac larvae & 1 & 0 & 0 & 0 & 0 \\
\hline Belonidae & Strongylura marina & 1 & 0 & 0 & 0 & 0 \\
\hline Ostraciidae & & 1 & 0 & 0 & 0 & 0 \\
\hline Microdesmidae & & 1 & 0 & 0 & 0 & 0 \\
\hline Elopidae & Elops sp. & 1 & 0 & 0 & 1 & 1 \\
\hline Ephippididae & & 1 & 0 & 0 & 1 & 1 \\
\hline Gobiidae & type III (Evorthodus lyricus) & 1 & 0 & 0 & 1 & 1 \\
\hline Scaridae & & 1 & 0 & 0 & 1 & 1 \\
\hline$\Sigma$ & & 2221 & & 187 & & 607 \\
\hline
\end{tabular}

Tropical Oceanography, Recife: v. 29, n. 2, p. 117-128, 2001. 
Table 1 - (continued)

\begin{tabular}{lrrrrrr}
\hline & Species & Total & \multicolumn{2}{c}{$\begin{array}{c}\text { Day catches } \\
\text { (only May '94) }\end{array}$} & \multicolumn{2}{c}{$\begin{array}{c}\text { Night catches } \\
\text { (only May '94) }\end{array}$} \\
& & Counts & Presence & Counts & Presence & Counts \\
\hline Clupeiformes & indet. & 25 & 2 & 3 & 5 & 22 \\
Pleuronectiformes & indet. & 1 & 0 & 0 & 1 & 1 \\
Perciformes & indet. & 0 & 0 & 0 & 0 & 0 \\
Postlarvae & indet. & 4 & 0 & 0 & 4 & 4 \\
Yolk sac larvae & indet. & 17 & 6 & 10 & 5 & 7 \\
$\sum$ indet. & & 47 & & 13 & & 34 \\
& & & & & & \\
$\sum$ total & 2268 & & 200 & & 641 \\
Fish Eggs total & & & & & & \\
Engraulis Eggs & 5350 & 25 & 1905 & 22 & 3445 \\
& & 1017 & 18 & 269 & 17 & 748 \\
\hline
\end{tabular}

Figure 4 - Composition of ichthyoplankton in the three areas and two seasons, given as percentage of the mean catch. The "May"-samples are shown separately because of the more intensive sampling.

\begin{tabular}{|c|c|c|}
\hline$\square 7$ Clupe & Sciaenidae (4 types) & 曲 Gobiidae (?) - YSL \\
\hline 四 Clupeidae & $\triangle$ Gobiidae Type I & Z Achirus spp. \\
\hline ПII Engraulidae & $\mathbf{W}$ Gobiidae Type II & Tetraodontoidei (?) - YSL \\
\hline Anchoa sp. & Gobiidae Type IV & $\square$ others \\
\hline
\end{tabular}

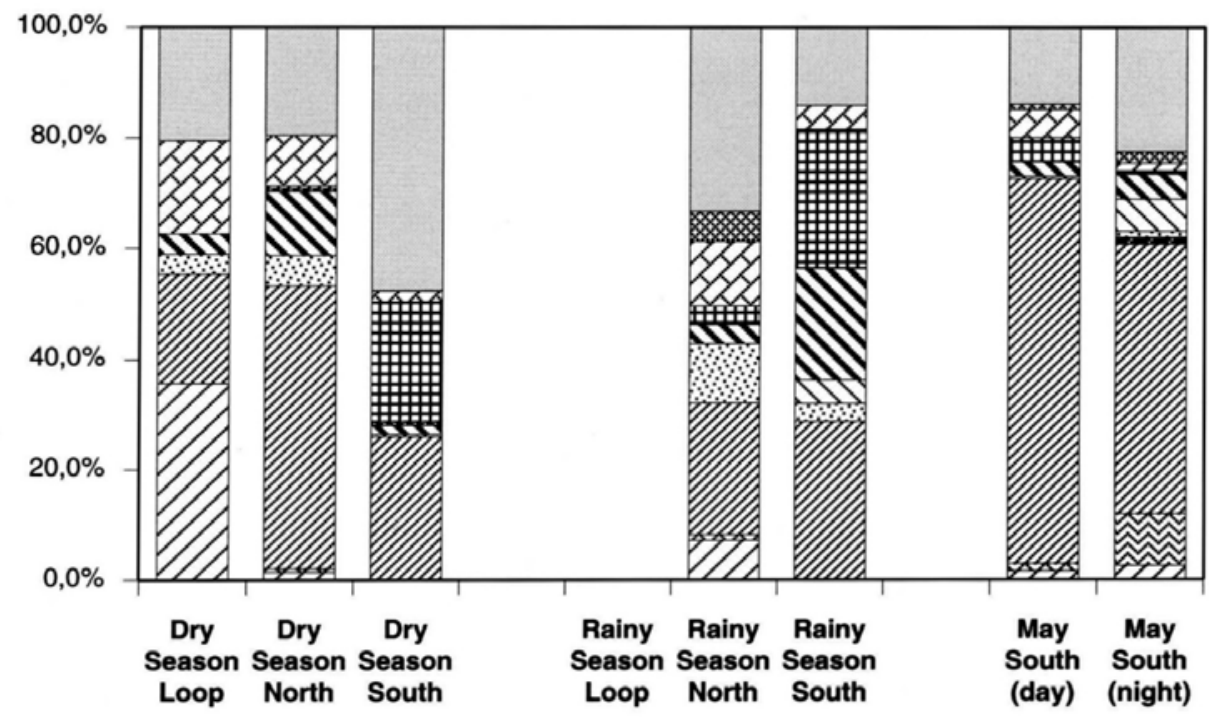

Tropical Oceanography, Recife: v. 29, n. 2, p. 117-128, 2001. 


\section{DISCUSSION}

The investigations described in this work together with a M.Sc.-thesis (Wenzel, 1995) are the first on ichthyoplankton in the Northeast of Brazil. The work of Wenzel was restricted to a short period in September and October 1993. As tropical estuaries in connection with mangrove vegetation are regarded as primary nursery grounds for many marine fishes, this project was designed to produce a first overview on the species inventory of a mangrove estuary in Northeast Brazil and to evaluate its importance for the adjacent waters.

Eskinazi (1972) and Macedo and Koening (1987) reported of 58 fish families occurring in the estuaries of Pernambuco as adults. The larval fish fauna is poorer. Only 22 families were found in the samples of this study, 16 of which are also found as adults. This is also less than found in other mangrove areas: Louis et al. (1992) found 42 families (87 species), Tzeng and Wang (1992) 55 families (125 species) and Thollot (1992) 64 families (262 species). They represent the most abundant groups in adults and larvae as well, like Engraulidae, Clupeidae, Gobiidae, Carangidae and Sciaenidae. The CSC waters thus showed a similar dominance in higher taxa as the Guaianese mangrove areas. The predominant groups in the work of Morais and Morais (1994) were engraulid and gobiid species and genera.

The larval and the adult (Börner, 1994) fish fauna in the CSC is dominated by engraulid species. Because of the small size of the caught larvae and the lack of adequate taxonomic literature, it is not possible to distinguish whether we deal with the same species in plankton and fisheries. The "Engraulidae", nevertheless, seem to play the most important role in this estuarine/nearshore system. Great numbers of engraulid eggs and young stage larvae indicate spawning activities in the estuary or in the nearcoast waters, respectively.

Only five families were represented exclusively by larvae: Achiriidae, Cottidae, Terapontidae, Exocoetidae and Ephippididae. The first three of these were found in higher numbers (see tab. 1).

These results demonstrate, that the "CSC"-estuary is not frequented by many offshore fish groups as nursery ground. The majority of fishes present in the estuarine ichthyoplankton are coastal marine or intertidal taxa, which may spend parts of their adult life in the brackish channel water. Only Achiriidae, Cottidae, Exocoetidae and Terapontidae release their larvae into the estuary and are not present as adults. From these four, the only oceanic group is the Exocoetidae family, living epipelagic and oceanic as adults. The abundance of this group within the samples was low, however.

The horizontal distribution of the larvae is less distinct than expected. Higher concentrations, however, were found mainly at the southern channel mouth and in the North at the more interior stations (2 and 3). This pattern may be influenced by the hydrographical and topographical features dominating the channel. The fish larvae in the "CSC"-estuary seem to prefer areas, which reflect a compromise between water masses exposed to exchange processes for supply of nutrients and sufficient protection for a stable development. The topography of stations 2 and 7 fulfilled these requests and supported high larval concentrations. On the other side very shallow mangrove areas with partly large intertidal mud flats were avoided in the North (stations. 8, 9, 10) and South (stations. $3,5,6$ ). The same holds for station 1 , which is characterised by a strong marine influence and high currents.

Seasonality was not very pronounced on the family level. Albaret and Ecoutin (1990) and Plumstead (1990) found influences of the freshwater input on the ichthyofaunal composition in estuaries. A reason why we could not find significant differences could be the weak rainy season in 1993, which was extremely poor in rainfall.

In terms of mangrove density and hydrographical and topographical conditions the Itamaraca area may serve as an example for the mangrove ecosystems along the East and Northeast

Tropical Oceanography, Recife: v. 29, n. 2, p. 117-128, 2001. 
Brazilian coast. With its dominance in estuarine and nearshore fish taxa, the CSC system is of great importance as nursery area for the coastal fishes, supporting abundant groups like Engraulidae, which are exploited by the artisanal fishery. The system seems to be not important for offshore species. This, on the other hand, may be caused by the low productivity and consequently low fish stocks of the shelf waters.

Dennis (1992) compared the role of mangroves as nursery area from island and continental coasts. He stated, that at least on islands, the importance of mangroves may be over estimated. Even if we still have to investigate the gradient from the estuary to the continental shelf in taxa composition and abundance to quantify the influence of the CSC-mangroves on the shelf fauna, the ichthyoplankton community structure in the channel may be a hint, that mangroves are not per se important fish nurseries. Many factors are influencing it, specially hydrographical and topographical features in front of the estuary. By that, the low overlap of taxa inventory between mangroves and adjacent systems (seagrass meadows or coral reefs), shown by Thollot and Kulbicki (1988) and Thollot (1992), may be explained.

\section{ACKNOWLEDGEMENT}

This work is based on a co-operative project on the "Ecology of the Canal de Santa Cruz" between the Department of Oceanography of the Federal University of Pernambuco and the Center for Tropical Marine Ecology, financed by the German Federal Ministry for Education, Science, Research and Technology (BMBF) under the grant number 0339607A.

\section{REFERENCES}

AHLSTROM, E. H.; MOSER, H. G.Ontogeny and systematics of fishes, based on an international symposium dedicated to the memory of Elbert Halvor Ahlstrom. In: International Symposium on Ontogeny and Systematics of Fishes. Proceedints... La Jolla, CA (USA), 15 Aug 1983. American Soc. of Ichthyologists and Herpetologists USA 1984. no. 1,

ALBARET, J. J.; ECOUTIN, J. M. Influence des saisons et des variations climatiques sur les peuplements de poissons d'une lagune tropicale en Afrique de l'Ouest. Acta Ekologia 11, 557583, 1990.

ANONYMOUS Development of Fishes of the Mid-Atlantic Bight. Fish and Wildlife Service, US Department of the Interior, 1978, 6 volumes

BLABER,S. J. M.; YOUNG, J. W.; DUNNING, M. C. Community structure and zoogeographic affinities of the coastal fishes of the Dampier region of north-western Australia. Aust. J. Mar.

Freshw. Res. 36, 247-258, 1985.

BLABER, S. J. M.; BREWER, D. T.; SALINI, J. P. Species composition and biomasses of fishes in different habitats of a tropical northern Australian estuary: Their occurrence in the adjoining sea and estuarine dependence. Estuarine Coastal Mar. Sci., 29(6), 509-531, 1989

BLABER, S. J. M.; BREWER, D. T.; SALINI, J. P. Fish communities and the nursery role of the shallow inshore waters of a tropical bay in the Gulf of Carpentaria. Australia. Estuarine Coastal Shelf Sci, 40, 177-193, 1995

Tropical Oceanography, Recife: v. 29, n. 2, p. 117-128, 2001. 
BOLTOVSKOY, D. (ed.) Atlas of the zooplankton of the southwestern Atlantic and methods in marine zooplankton research. Mar del Plata, Argentina, Inst. Nac. Invest. Desarr. Pesq. 1981, 936p. (in Spanish)

BÖRNER, R. Fischereibiologische Untersuchungen an den Fischbeständen des Canal de Santa Cruz, Pernambuco, Brasilien. Bremen: 1994, 75p.Thesis (M.Sc) - University of Bremen,

CHONG, P.W. Proposed management and integrated utilization of mangrove resource in Sierra Leone, Freetown. Project UNDP/FAO: SIL/84/003. Field Document No. 6, 1987, 123p.

DENNIS, G. D. Island mangrove habitats as spawning and nursery areas for commercially important fishes in the Caribbean: In: Gulf and Caribbean Fisheries Institute, $41^{\text {th }}$, Proceedings... 205-225, 1993.

DITTY, J. G; SHAW, R. F.Larval development of tripletail, Lobotes surinamensis (Pisces: Lobotidae), and their spatial and temporal distribution in the northern Gulf of Mexico. Fish. Bull. v. 92, n. 1, p. 33-45, 1994.

DITTY, J. G. Separating early larvae of sciaenids from the western North Atlantic: A review and comparison of larvae off Louisiana and Atlantic coast of the U.S. Bull. Mar. Sci., v. 44, n. 3, p. 1083-1105, 1989

ESKINAZI, A. M. Peixes do Canal de Santa Cruz - Pernambuco - Brasil. Trab. Oceanogr. Univ. Fed. PE. 13, 283-302, 1972.

FAHAY, M. P. Guide to the Early Stages of Marine Fishes Occuring in the Western North Atlantic Ocean, Cape Hatteras to the Southern Scotian Shelf. J. Northw. Atl. Fish. Sci. 4, 1983, 423 pp.

FOSTER, N. R.; Fuiman, L. A. Notes on behavior and early life history of captive lyre gobies, Evorthodus lyricus. Bull. Mar. Sci., v. 41, n. 1, p. 27-35. 1987.

LEIS, J. M.; RENNIS, D. S. The larvae of the Indo-Pacific Coral Reef Fishes. New South Wales Univ. Press, Sydney, and Hawaii Press, Honolulu, 1983, 269p

LEIS, J..; TRNSKI, T. The larvae of Indo-Pacific shorefishes. Univ. of Hawaii Press, Honolulu, 1989.

LOUIS, M., BOUCHON, C., BOUCHON-NAVARO, Y. The ichtyological fauna of the mangrove in the bay of Fort-de-France (Martinique Island). Cybium, v. 16, n. 4, p. 291-305, 1992. [In French]

MACEDO, S. J.; KOENING, M. L. Áreas estuarinas do Estado de Pernambuco (Bibliografia comentada). Universidade Federal de Pernambuco, Departamento de Oceanografia, Recife, 1984, 350p.

MEDEIROS, C.; KJERFVE, B.Hydrology of a tropical estuarine system: Itamaraca, Brazil. Estuarine Coastal Mar. Sci., v. 36, p. 495-515, 1983.

MORAIS, A.T. de; MORAIS, L. T. de. The Abundance and Diversity of Larval and Juvenile Fish in a Tropical Estuary. Estuaries, v. 17, n. 1B, p. 216-225, 1994.

Tropical Oceanography, Recife: v. 29, n. 2, p. 117-128, 2001. 
OKIYAMA, M. (ed.). An atlas of the early stage fishes in Japan. Tokai Univ. Press, Tokyo, 1988, $1154 \mathrm{pp}$.

PETERS, K. M. Larval and early juvenile development of the Frillfin Goby, Bathygobius soporator (Perciformes: Gobiidae). Northeast Gulf Sci, v. 6, n. 2, p. 137-153, 1983.

PEZOLD, F.; GILBERT, C. R. Two new species of the Gobiid fish genus Gobionellus from the Western Atlantic. Copeia, v. 1, p. 169-175, 1987.

PLUMSTEAD, E. E. Changes in ichthyofaunal diversity and abundance within the Mbashe estuary, Transkei, following construction of a river barrage. S. Afr. J. Mar. Sci, v. 9, p. 399-407, 1990.

POWLES, H.; STENDER, B.W.Taxonomic data on the early life history stages of the of the South Atlantic Bigth of the United States. Mar. Resources Res. Inst., 31, 1-64, 1978.

ROBERTSON, A. I.; DUKE, N. C. Mangroves as nursery sites: Comparisons of the abundance and species composition of fish and crustaceans in mangroves and other nearshore habitats in tropical Australia. Mar. Biol., v. 96, n. 2, p. 193-205. 1987.

RUSSELL, F. S. The eggs and planctonic stages of British marine fishes. Academic Press, London. 1976, 524 pp.

SINQUE, C. Larvas de Sciaenidae (Teleostei) identificadas na Regiao Estuarino-Langunar de Cananeia. Bol. Zool. Univ. São Paulo, v. 5, p. 39-77, 1980.

STEEDMAN, H.F. (ed.). Monographs on oceanographic methology. 4. Zooplankton fixation and preservation. Unesco Press, Paris. 1976, 350 pp.

THOLLOT, P. Importance of mangroves for the reef fish fauna from New Caledonia. Cybium, v. 16, n. 4, p. 331-344. 1992. [In French]

THOLLOT, P.; Kulbicki, M., Overlap between the fish fauna inventories of coral reefs, soft bottoms and mangroves in Saint Vincent Bay (New Calidonia). In: International Coral Reef Sympos. 2, Proceedings... 1988, p. 613-618

TZENG, W. N.; Wang, Y. T. Structure, composition and seasonal dynamics of the larval and juvenile fish community in the mangrove estuary of Tanshui River, Taiwan. Mar. Biol, v. 113, n. 2 p. 481-490, 1992.

WENZEL, S. Vorkommen und räumliche Verteilung von Fischbrut im Canal de Santa Cruz, Nordost-Brasilien. Bremen: 1995, 82p. Thesis (M.Sc) - University of Bremen, 82 pp.

WYANSKI, D. M.; Targett, T. E. Juvenile development of the lyre goby, Evorthodus lyricus (Girard) (Pisces: Gobiidae), with a discussion of early life history. Bull. Mar. Sci., v. 36, n. 1, p. 115-123, 1985. 